\title{
THE OSTEOLOGY AND OSSIFICATION VARIABILITY OF THE SKULL OF ANTARCTIC WHITE-BLOODED FISH CHAENODRACO WILSONI REGAN, 1914 (CHANNICHTHYIDAE, NOTOTHENIOIDEI) OSTEOLOGIA I ZMIENNOŚĆ SKOSTNIEŃ CZASZKI ANTARKTYCZNEGO GATUNKU CHAENODRACO WILSONI REGAN, 1914 (CHANNICHTHYIDAE, NOTOTHENIOIDEI, PISCES)
}

\begin{abstract}
Department of Paleozoology, Zoological Institute, University of Wroclaw, Poland
\end{abstract}
A detailed osteological analysis of the skull of an Antarctic fish, Chaenodraco wilsoni Regan, 1914 (Channichthyidae, Notothenioidei) was done, focusing on the bone structure and osteological variability. A notable reduction of the ossification was observed, which took place in several ways: replacement of the whole bone with cartilage, only superficial ossification (e.g. in the ethmoid region), separation of the bones by wide cartilage areas (e.g. in the brain case), and reduction of bone dimensions. An extreme case was complete loss of the opisthootic - the first record of this kind within this family of fishes. The reduction of ossification in Ch. wilsoni resulted in high osteological variability that was observed in the case of reduced bones. Instances of assymmetry of paired elements of the skeleton were observed as well.

\section{INTRODUCTION}

The history of scientific Antarctic research was not been long, as it only started in the $19^{\text {th }}$ century, when the south polar regions were reached. That was when scientists began to organise expeditions, intending to study the Antarctic fauna. Therefore it is not surprising that the current knowledge on Antarctic organisms is uncompleted and requires further investigation. Also the fish fauna which evolved in severe climatic conditions and in isolation, restricted by the Antarctic Convergence needs additional studies. Cold Antarctic waters contact warmer temperate waters and due to density differences sink deeper, making the barrier difficult to cross for many organisms (Jakubowski 1971). In those conditions evolved a specific branch of Perciformes-the suborder Notothenioidei, consisting of the following 5 families: Bovichthyidae, Nototheniidae, Harpagiferidae, Bathydraconidae, and 
Channichthyidae. At present, the notothenioid fishes are the predominant component of the Antarctic ichthyofauna, consisting of about 130 species assigned to 47 genera, what makes $75 \%$ of the species number (Andriašev 1965) and over $90 \%$ of the estimated specimen number (DeWitt 1971). The most extensively specialised group is the family Channichthyidae, which developed a peculiar feature, unique among vertebrates-hereditary white-bloodedness. The blood of these fishes is deprived of erythrocytes and haemoglobin. A lack of respiratory pigment is compensated by several adaptations: white-blooded fishes have higher blood volume than other fishes, which can be evidenced by big cross-sections of the heart and blood vessels. All the body surfaces that are in contact with water are extensively vascularized, which enhances the gas exchange. For the same effect, proportions of the body are unusual: big head, large fins. Those features, in conjunction with high oxygenation of the Antarctic waters, can compensate for the lack of erythrocytes (Jakubowski 1971).

The present study concerns Chaenodraco wilsoni Regan, 1914 a white-blooded species belonging to the family Channichthyidae, occuring in the whole Antarctic (Olsen 1955; Permitin 1977; Gerasimčuk and Trocenko 1988). Depending on the phase of life cycle and season, Ch. wilsoni occurs at various depths, from upper layers to the depths of about $470-500 \mathrm{~m}$. The adults occur mostly at depths of 50-400 m, where the temperature of water ranges from $-1.2^{\circ} \mathrm{C}$ to $-1.4^{\circ} \mathrm{C}$, and the salinity from 34.3 to $34.4 \%$, while most specimens remain in the benthic layers. The reproduction takes place in January. Deposited spawn sink to the bottom. After hatching, the larvae go to the upper layers of water and feed on zooplankton. Young specimens lead a pelagic mode of life. The main food base for the juveniles and adults is the Antarctic krill, Euphausia superba (cf. Gerasimčuk and Trocenko 1988). The body shape of Ch. wilsoni is typical for white-blooded fishes (Fig. 1): a big head with dorso-ventrally flattened snout, 2 dorsal fins, pelvic fins displaced on the throat area, large fan-shaped pectoral fins, naked body (remains of scales are preserved in the lateral line). Three lateral lines appear on the body: first-near dorsal edge of the body, from the head to the caudal section, second-only on the caudal section, third-above the lower edge of the body, from the area beyond the anus to the caudal section.

Osteology and phylogeny of white-blooded fishes have been extensively reviewed by Iwami (1985). His large work covers 14 out of 18 known species of this family. Voskobojnikova $(1982,1986)$ and Baluškin (1992) focused on this area as well. Baluškin described the origin and relationships within suborder Notothenioidei.

The aim of the present work was to provide a complete analysis of the skull bones of Ch. wilsoni, and to examine osteological variability within the species. The author was also trying to find factors that had influenced the development of the specific structures of this fish's skull. 


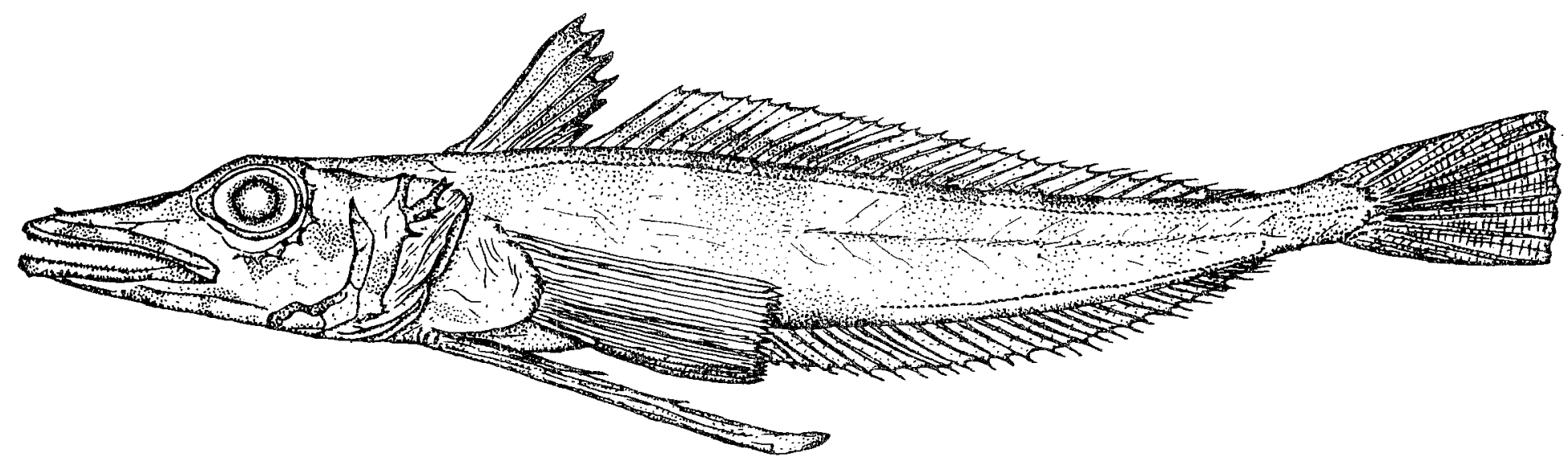

Fig. 1. General view of the body of Chaenodraco wilsoni; specimen no. 2 


\section{MATERIAL AND METHODS}

The material for the present osteological study consisted of 6 out of 13 specimens of Chaenodraco wilsoni Regan, 1914, from the collection of the Department of Vertebrate Zoology (University of Wrocław). All of them were collected during the Antarctic "Sibex" expedition in December 1983 in the region of Joinville Island (West Antarctic). These specimens were fixed in formalin and transferred to $70 \%$ ethanol after a year. Specimens marked by numbers $1,3,6,7,8,12$ were used for the study on the skull osteology. Selected plastic features of the specimens of Ch. wilsoni are described in Tab. 1.

Table 1

Selected plastic features of examined specimens of Chaenodraco wilsoni

(in mm, abbreviations according to Holčik 1989)

\begin{tabular}{|c|r|r|r|r|r|r|r|r|r|r|r|r|r|}
\hline $\begin{array}{c}\text { Measure- } \\
\text { ment }\end{array}$ & \multicolumn{10}{|c|}{1} & \multicolumn{10}{|c|}{3} & \multicolumn{10}{|c|}{4} & 5 & 6 & 7 & 8 & 10 & 11 & 12 & 13 & 15 \\
\hline \multicolumn{1}{c|}{252} & 249 & 230 & 277 & 242 & 236 & 245 & 250 & 252 & 229 & 243 & 240 & 290 \\
\hline$S l$ & - & 217 & - & 246 & 213 & - & - & 222 & 221 & 204 & - & 212 & 260 \\
\hline$p r O$ & - & 29.0 & - & 29.0 & 29.5 & - & - & 31.0 & 37.5 & 29.0 & - & 34.0 & 32.0 \\
\hline las & - & 22.0 & - & 23.5 & 17.4 & - & - & 20.5 & 24.0 & 22.0 & - & 24.0 & 32.0 \\
\hline$l a c$ & - & 27.0 & - & 32.5 & 27.8 & - & - & 27.6 & 31.0 & 29.7 & - & 28.0 & 37.0 \\
\hline$h c$ & - & 32.7 & - & 37.0 & 30 & - & - & 32.0 & 32.0 & 32.8 & - & 33.0 & 44.0 \\
\hline$O h$ & - & 14.0 & - & 16.0 & 14 & - & - & 16.0 & 15.0 & 14.0 & - & 14.0 & 19.7 \\
\hline$l c$ in $\% T l$ & - & 27.5 & - & 25.6 & 28.9 & - & - & 26.9 & 28.9 & 29.0 & - & 29.6 & 27.2 \\
\hline$H$ & - & 32.0 & - & 42.5 & 30.6 & - & - & 34.8 & 36.8 & 36.0 & - & 34.0 & 39.5 \\
\hline$h$ & - & 9.0 & - & 10.0 & 8.5 & - & - & 9.0 & 9.0 & 8.0 & - & 9.8 & 10.8 \\
\hline$l D_{1}$ & - & 19.0 & - & 24.0 & 18 & - & - & 18.0 & 16.5 & 16.0 & - & 19.0 & 27.0 \\
\hline$l D_{2}$ & - & 106 & - & 131 & 110 & - & - & 113 & 113 & 105 & - & 109 & 135 \\
\hline$l P$ & - & 45.0 & - & 50.0 & 42 & - & - & 48.0 & 44.0 & 45.0 & - & 41.5 & 52.5 \\
\hline$l V$ & - & 55.0 & - & 60.0 & 55 & - & - & 55.0 & 48.6 & 59.0 & - & 62.0 & 61.4 \\
\hline
\end{tabular}

Prior to the examination the fish soft tissues were cleared with $2-4 \% \mathrm{KOH}$ and the bones were stained with alizarin (modified method of Hollister 1934) to make the relevant structures better visible. During the clearing process, in order to protect the tissues against maceration, glycerine was gradually added to the $\mathrm{KOH}$ solution (from 20 to 100\%). In order to clear deeper interior bones, it was necessary to mechanically remove the muscle tissue and drops of fat. The results of the preparation were conserved in glycerine, yielding transparent fish with red skeletal elements.

Specimens with numbers 1, 3, and 8 were cleared and stained. Specimens Nos. 6, 7, and 12 after staining were macerated with higher concentration of $\mathrm{KOH}$ and gave single bones and groups of bones which were helpful during detailed osteological analysis and for making illustrations. 
Abbreviations used in the figures: ANG angular, ART articular, BOC basioccipital, CER ceratohyal, COR coracoid, DEN dentary, ECT ectopterygoid, ELP medial element, EPO epiotic, ETH ethmoid, ETHC ethmoid cartilage, ETL lateral ethmoid, EXOC exoccipital, FRO frontal, HYO hyomandibular, INO infraorbital, INT interhyal, IOPE interopercle, MAX maxillary, MET metapterygoid, NAS nasal, OPE opercle, PAL palatine, PAR parietal, PMAX premaxillary, POPE preopercle, POS posttemporal, PRO prootic, PTE pterotic, PTS pterosphenoid, Q quadrate, RAD radial, RADB branchiostegal ray, SCA scapula, SOC supraoccipital, SOPE subopercle, SPH sphenoid, SYM symplectic.

\section{RESULTS AND DISCUSSION}

Neurocranium

The neurocranium of Ch. wilsoni consists of ethmoid cartilage and the following bones: ethmoid, lateral ethmoids, prootics, epiotics, supraoccipital, exoccipitals, basioccipital, pterosphenoid, prevomer, nasals, frontals, parietals, parasphenoid, infraorbitals. There is no basisphenoid in the neurocranium, which is typical for the entire Channichthyidae family (Baluškin 1992). The opisthootic is completely reduced, which was not confirmed by the other authors (Fig. 2). Iwami (1985) described the opisthootic of Channichthyidae as a small reduced bone covering the cartilage between the pterotic and the exoccipital, but he did not confirm lack of this bone within the skeleton of any species of the family. As presently observed in Ch. wilsoni there is only a wide cartilaginous area in the place of opisthootic. It is therefore evident that a complete reduction of this bone took place, which can be regarded as a feature confirming high evolutionary position among other species of the family Channichthyidae.

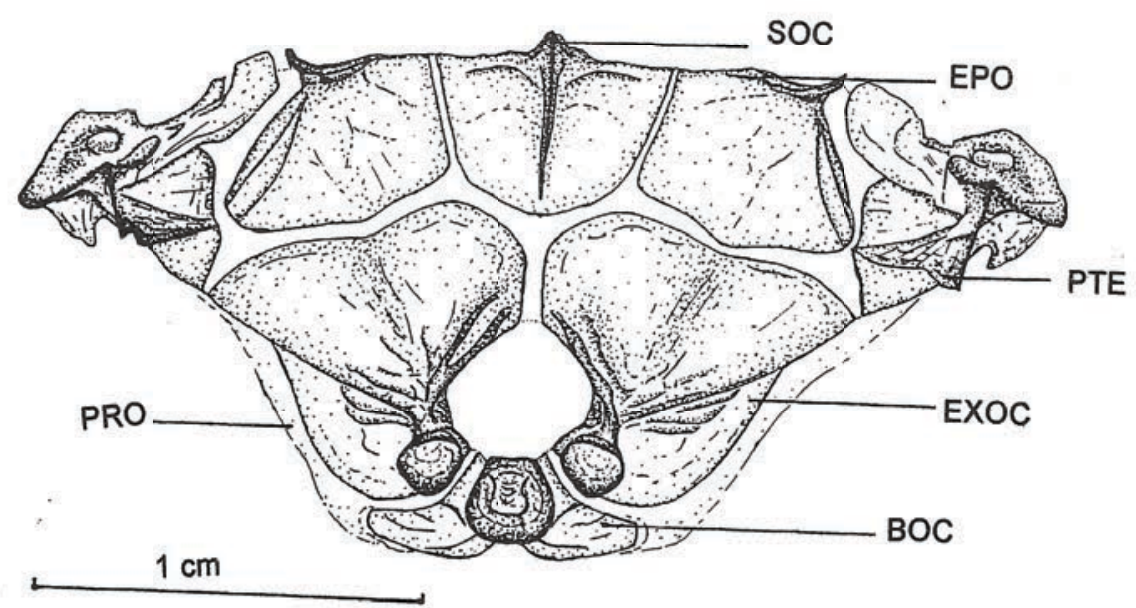

Fig. 2. Occipital region, specimen no 7; all the abbreviations describing figures and photographs are given in "Material and Methods" 
Neurocranium in the studied species shows a peculiar feature-a substantial reversal of ossification and replacement of the bone with cartilage. It is also a common feature among the other species of this family (Iwami 1985). A considerable part of the ethmoid region is the ethmoid cartilage, which is partially covered by bones lying in wide spaces (Phot. 1). Also connections of the brain case elements do not have a compact character. Individual bones connect to each other via bands of cartilage. The exception are several connections, e.g. sphenotic-pterotic, which is compact (Fig. 3, Phot. 2). Iwami (1985) observed the same state only in skeleton of Champsocephalus and Channichthys, which are considered to be primitive. Thus, it is a primary feature exceptionally preserved by $C h$. wilsoni. The reduction of infraorbitals is advanced; these small stick-shaped bones are limited to covering the infraorbital canal of the lateral line. The same feature applies to the nasals constructing the anterior part of the supraorbital canal. They are narrow, rainpipeshaped and some specimens have nasals closed in a central part that form a tubule.

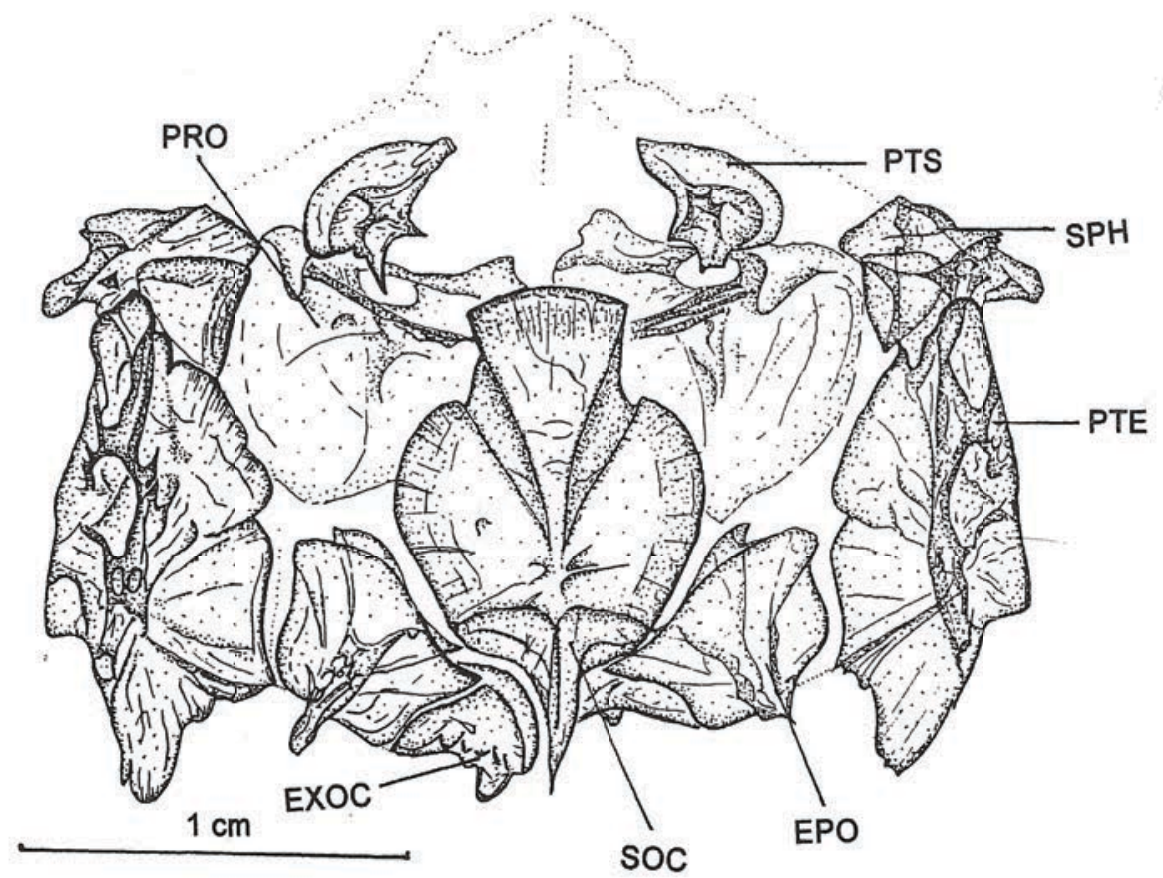

Fig. 3. Topography of bones of the brain case, dorsal view (parietals removed); specimen no. 12

\section{Splanchnocranium}

This part of the Ch. wilsoni skull is characterised by a notable reduction of ossification, which is manifested by wide cartilaginous areas between bone elements, and superficial ossification and reconstruction of whole bone groups (Fig. 4). The 


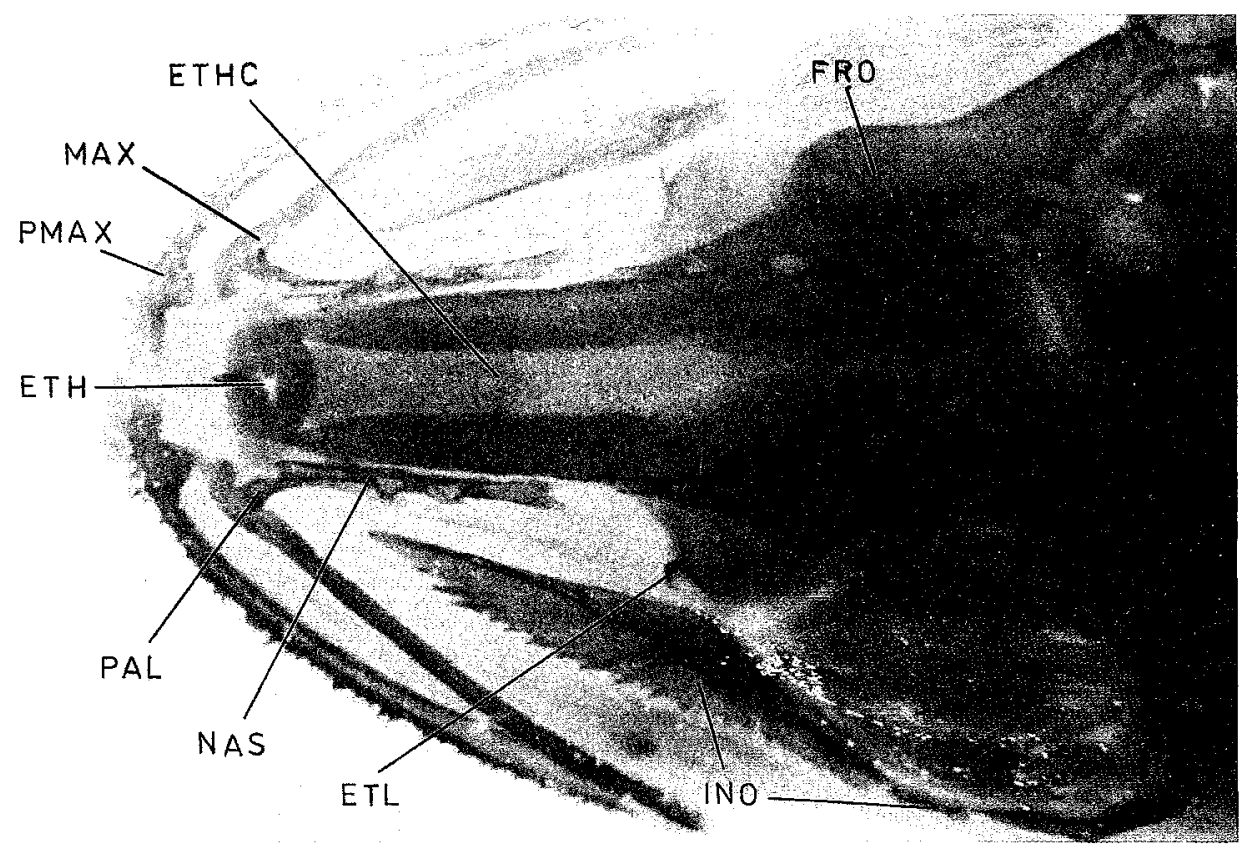

Phot. 1. Ethmoidal region, dorsal view (specimen no. $8 ; 3 \times$ )

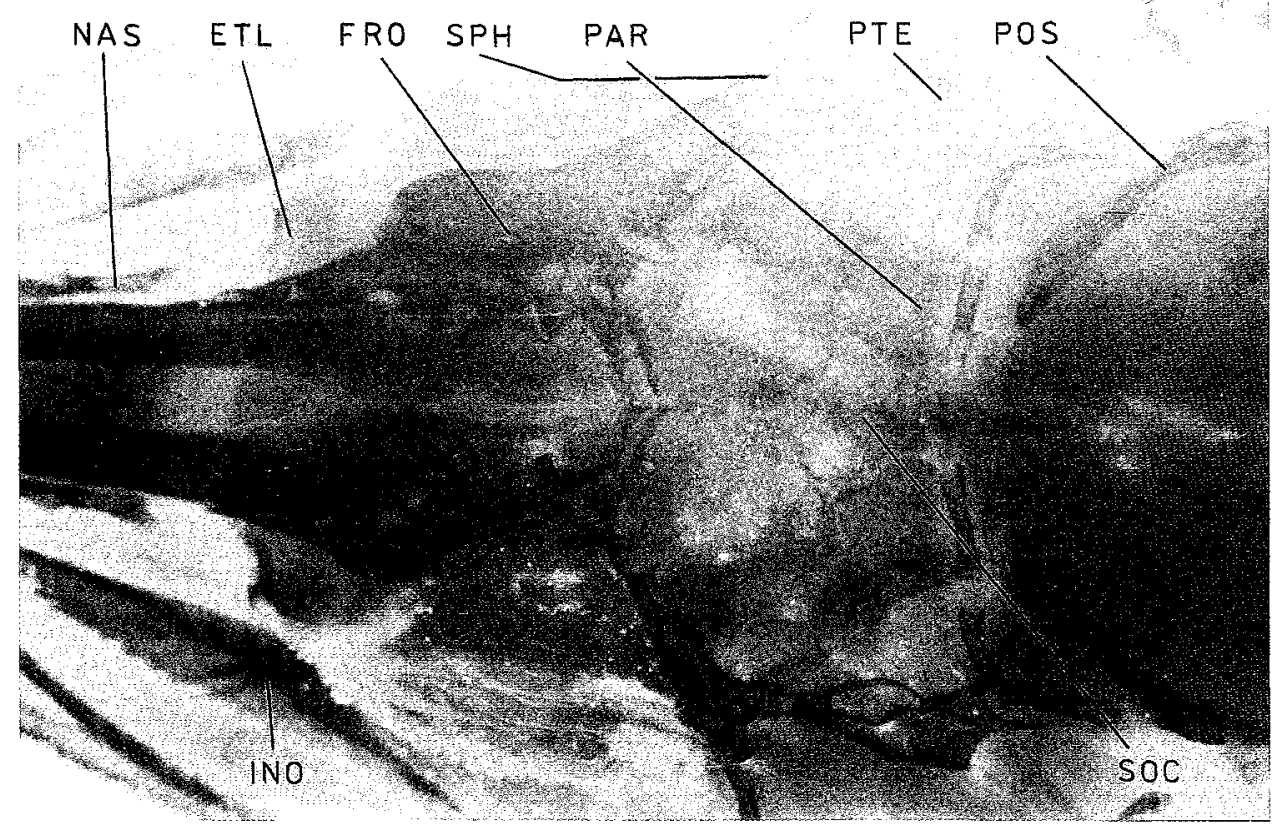

Phot. 2. Skull roof, dorsal view (left frontal faulted, speciman no. $8 ; 3.5 \times$ ) 


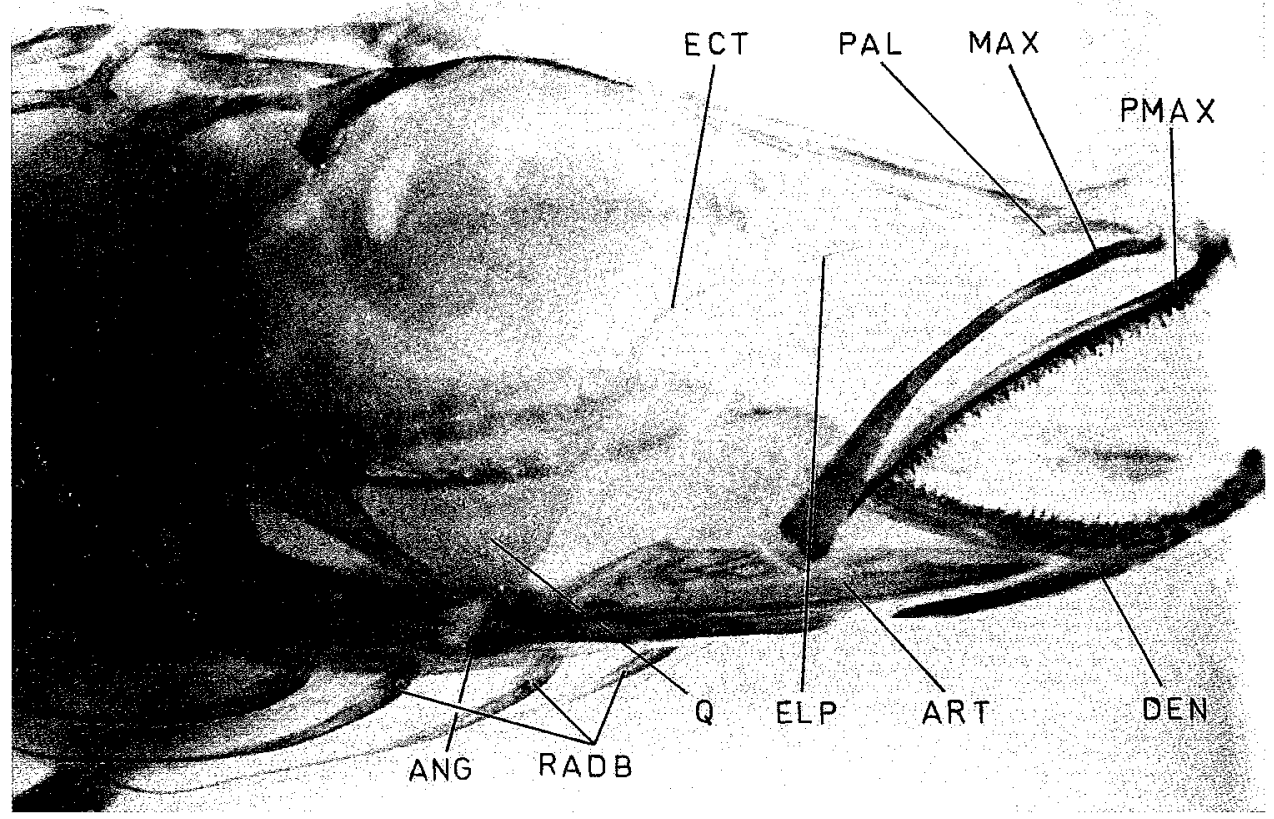

Phot. 3. Palatine and mandibular arches and elements of hyoid arch (infraorbitals removed, specimen no. $1 ; 2.5 \times$ )

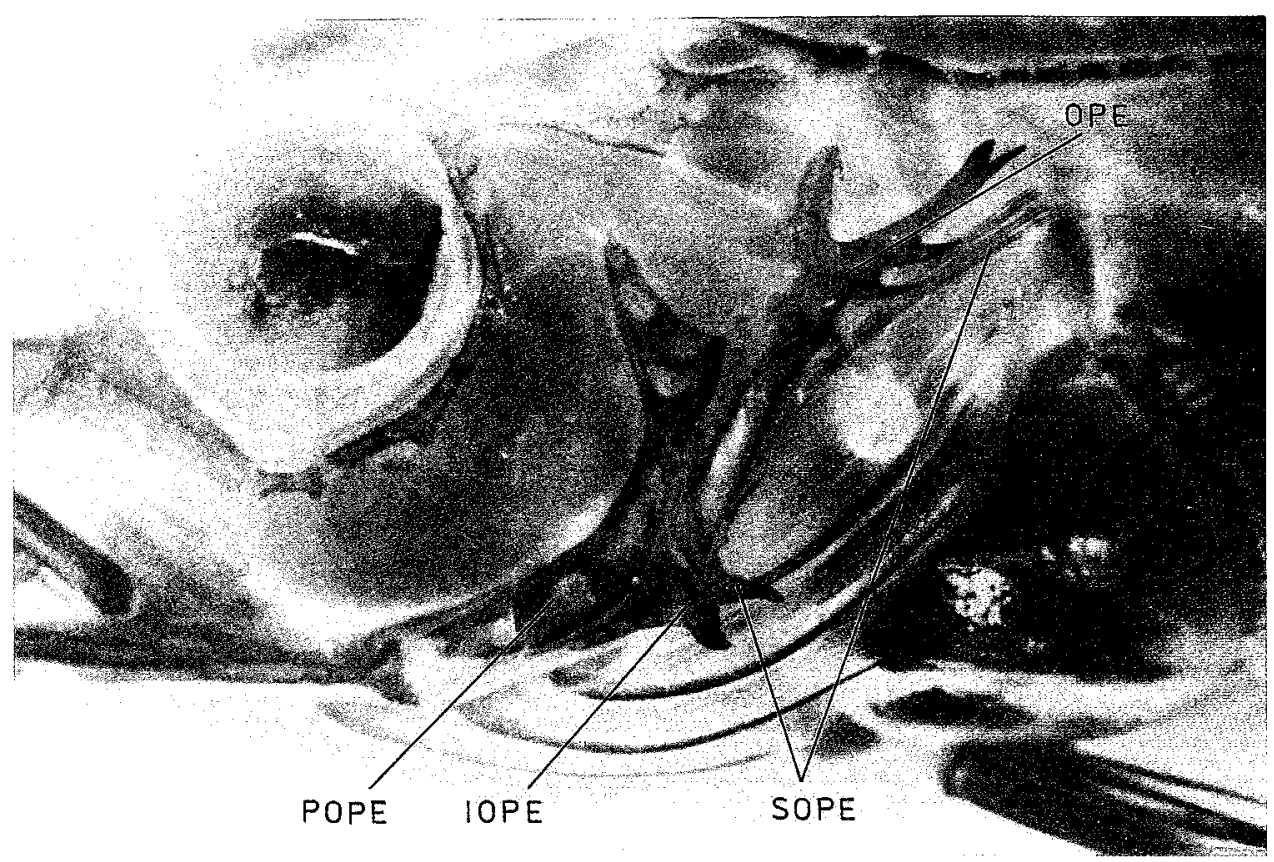

Phot. 4. Opercle, left side view (speciman no. $8 ; 4 \times$ ) 
splanchnocranium consists of 23 bones, which form bone arches: the mandibular, the hyoid, and the opercular apparatus. In the present study, with regard to specific structures of this region of the Ch. wilsoni head, a ptero-palatine part of the mandibular arch is described separately as the palatine arch. Bones of the branchial arch were not investigated.

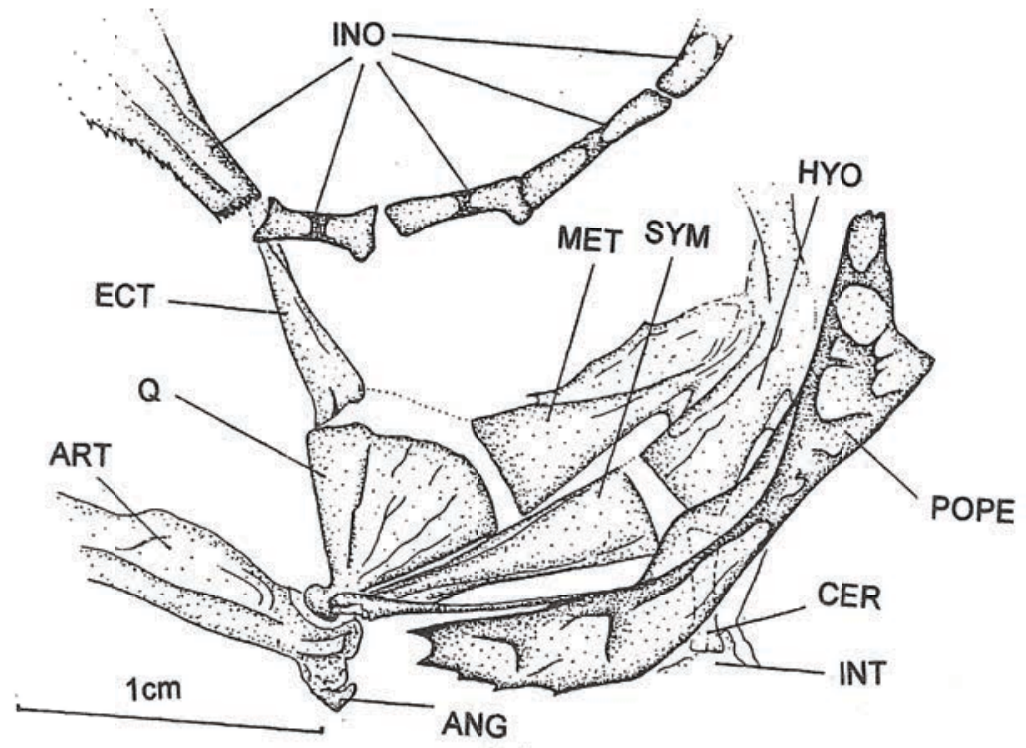

Fig. 4. Suspensorium, left side view; specimen no. 8

The mandibular arch is characterised by an elongation of bony elements due to the long pike-like snout and it is formed by the following bones: praemaxillaries, maxillaries, articulars, dentaries, and quadrates (Phot. 3). Ail of them are paired. The reduction of ossification is marked in this region and expressed by the existence of cartilaginous areas between bones, so that elements of the skeleton do not form close connections (e.g. dentary-articular connection).

The palatine arch of fishes from the suborder Notothenioidei is composed of the following bones: mesopterygoids, ectopterygoids, and palatines (all are paired). The arch connects upper jaw with bones of the lower jaw (through quadrate) and with the hyoid arch. Representatives of the family Channichthyidae, showing advanced reduction of ossification in the region were discussed (Phot. 3). This process contributed to a complete reconstruction of the palatine arch. For that reason, it is not easy to identify elements of the region and the other authors give different hypotheses to explain this state. Ch. wilsoni has 3 separate bones in the palatine arch. Doubtlessly, the bone laying most anteriorly is the 
palatine, and the posterior element is the ectopterygoid. The element which lays medially between two other bones is very strange and has been a subject of many discussions. In the present study this bone will be named "medial element". Authors of the earlier studies on the Antarctic fish osteology (Gill 1862; Regan 1913, 1914; Norman 1938) suggested that mesopterygoid of fishes of the family Channichthyidae disappeared and they identified the preserved bone of the arch as the ectopterygoid. Iwami (1985) applied the some name to it, however, he did not agree with the hypothesis of the loss of the mesopterygoid. According to this author, the distinctly separated bony medial element, is the reduced mesopterygoid, which was displaced from the primary place (medially in relation to the ectopterygoid) to the place between the palatine and the ectopterygoid. A precise analysis of the palatine arch of Ch. wilsoni seems to confirm the view mentioned above. The following features were observed: a distinct separation of the medial element from other bones (particularly transparent visible on border with the palatine) and an elongation of the snout, which is connected with the elongation of the palatine arch, and causes a forward displacement of the mesopterygoid. Voskobojnikova $(1982,1986)$ suspected that the ectopterygoid and the mesopterygoid fused into a single element (Iwami interpreted this one as the ectopterygoid). The medial element, according to Voskobojnikova, is an elongated, poorly ossified, and separated posterior part of the palatine, which could not be regarded as the mesopterygoid, because no work on embryology of Channichthyidae had proved displacement of this bone. There is no doubt that it is an important argument, but it could turn out to be a result of insufficient knowledge about the skeletal development of these fishes. Division of the palatine into 2 parts resulting in a reduction of ossification seems to be probable, considering that the bone has a mixed character (the anterior, more massive part of the palatine would represent a bone of dermal origin and posterior - the mediat elementa bone of cartilaginous origin). However, different views of adjacent areas of the anterior part of the palatine and of the medial element (this part of the palatine is wide and dulltipped, but the medial element is thin, pointed) suggest that both elements did not make a single bone. The assumption mentioned above prooves that it is very difficult to trace the origin of palatine arch elements of Ch. wilsoni.

The hyoid arch of Ch. wilsoni consists of the following bones: hyomandibulars, symplectics, interhyals, epihyals, ceratohyals, and branchiostegal rays. Due to its important role in joining elements of the skull, in the case of the hyoid arch a reduction of ossification, like in the palatine arch, did not take place. However, it is visible, particularly in the case of the anterior part of the hyoid arch. The reduction manifests itself by a thinning of certain elements (e.g. ceratohyals are very long and thin), and by a replacement of bone tissue with cartilage (e.g. most part of the mass of the hypohyal is a cartilage, which ossifies only on the ventral side). 
The attachment of the branchiostegal rays to the ceratohyal in the skeleton of the discussed species is characteristic only for Ch. wilsoni. Other species of the family Channichthyidae have the first or the first and second ray attached to the ceratohyal medially, but $C h$. wilsoni has every ray attached laterally.

The opercular apparatus of $C h$. wilsoni is composed of the following paired bones: praeopercles, opercles, subopercles, and interopercles (Phot. 4). It is characteristic that a reduction in the opercle size took place. The same state is observed in skeletons of all channichthyid fishes (Iwami 1985). The preopercle is limited to covering the hyomandibular canal of the lateral line. The opercle was reduced to 2 branches, from which the posterior one is equipped with spines and it has a mainly defensive function. The subopercle ossifies only in the lower part, however its upper membrane-like part functions as a proper gill cover. The interopercle was reduced to a small, triangular element. The process of reduction of the opercular apparatus can be explained by phenomena which accompany white-bloodedness: reduction of the gill surface and a reduction gill v. skin area ratio, giving priority to the body surface, which takes over the respiratory function through its high density of subepithelial capillaries (Jakubowski 1971).

The pectoral girdle of $C h$. wilsoni consists of 9 paired bones, of which 5 build the primary pectoral girdle which has cartilaginous origin (these are: scapulae, coracoids, radials; Fig. 5), and 3 form the secondary pectoral girdle which has dermal origin (these are: cleithrals-Fig. 6, supracleithrals, posttemporals). The postcleithral is not present-it is a feature of the whole family Channichthyidae (Iwami 1985), characterised by poor ossification of the girdle elements, particularly in the primary part. Radials are wide, flattened (this is a typical state for notothenioid fishes), and ossified only in the regions of ossification centres.

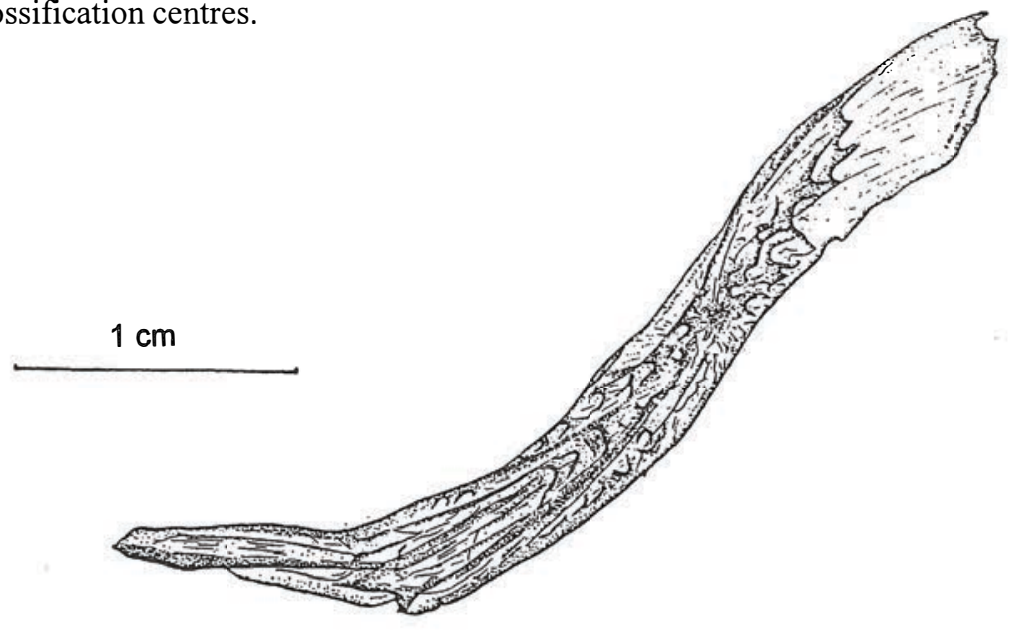

Fig. 5. Cleithral, left side view; specimen no. 12 


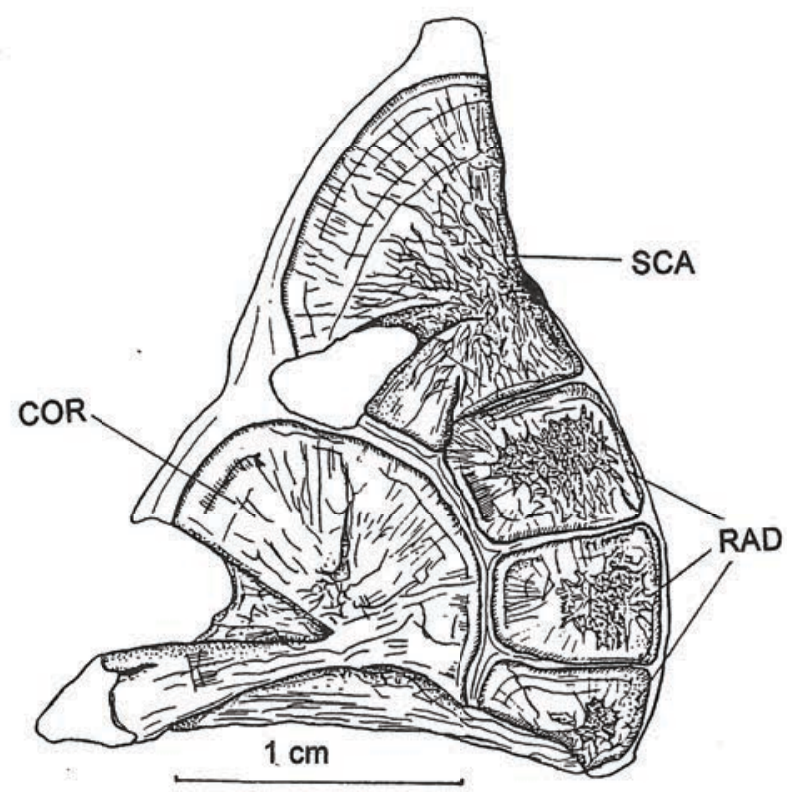

Fig. 6. Elements of the primary pectoral girdle, specimen no. 12

\section{Variability of bones}

There is an extensive variability in the skull structure of $C h$. wilsoni, not only in the size of individual bones, but also in their shapes, and proportions. These differences may be examined in two aspects: an interindividual variability affecting all bones, and differences between the right and left side of the body, affecting only paired bones. In the present description, only the elements showing significant variability were taken into consideration.

Ethmoid. A bone which demonstrates moderate variability, depending on differences of the border shape and length, and a form of the process, which can reduce itself to small convexity or form a well-developed process-rostrum.

Lateral ethmoid. Minor variability which is limited to differences in the shape of the anterior process.

Nasal (Figs. 7a, b, c). A notable variability in the bone shape. Differences are visible in the form of the endings and in the distribution of lateral line pores, as well as in the asymmetry of the left and the right nasal (specimen No. 12).

Prevomer (Figs. 7d, e, f). Large variability, both in the shape and in the size. Differences in the form of the wide anterior part and in the shape and length of the narrow posterior part. In specimen No. 12 this component is short and blunt, and in specimens Nos. 6 and 7 it is long and pointed. 

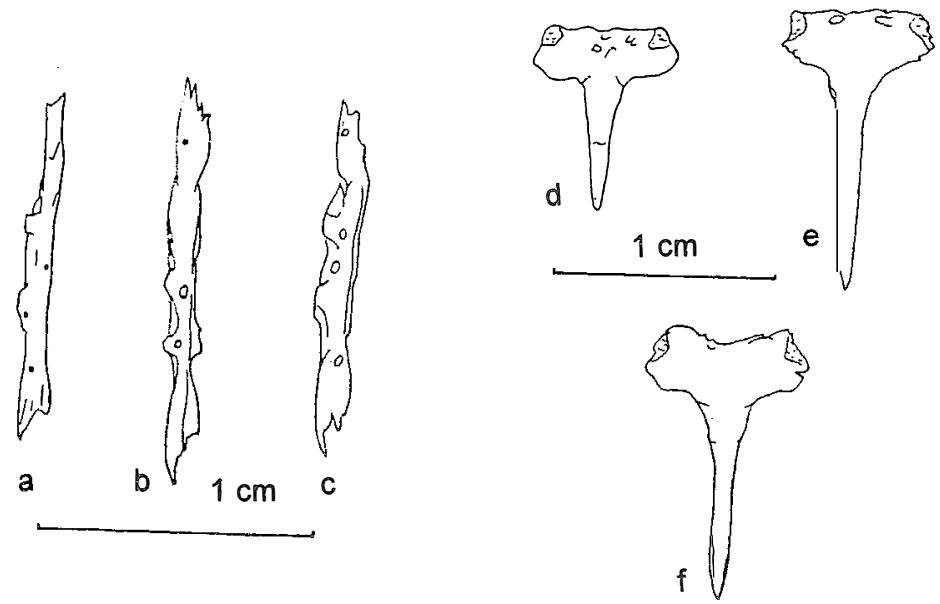

Fig. 7. Variability of bones: nasal $(a, b, c)$ and prevomer $(d, e, f) ; a, d-$ specimen no. 12; b, e-specimen no. 6 ; c, f-specimen no. 7

Frontal. Significant variability expressing differences of convexity on the part covering the orbit, the distribution, and the shape of lateral line pores and the outline of the medial and posterior edge. A number of pores can be asymmetric. There are 3 pores in specimen No. 12 in the anterior part of the canal on the left, but 4 pores on the right.

Pterotic. Moderate variability in the lateral plate of the bone with a free border (in its posterior part only). Asymmetry of pterotics on the left and on the right is visible as well (specimen No. 12).

Epiotic. A small variability of the posterior process which has a different shape on the left and on the right.

Parietal. Medium variability, marked in the shape of this bone.

Supraoccipital. Small variability, in the form of posterior crest edges.

Exoccipital. Minor variability, marked only by the shape of anterior outgrowths that connect with the basioccipital.

Parasphenoid. Major variability, particularly in the posterior part of the bone. Differences in the shape, length of the posterior spatular section and in the form of lateral semicircular cuttings.

Pterosphenoid (Figs. 8d, e). Very notable variability in the bone shape, particularly on the medial side. A variability between bones of the right and left sides of the body, visible particularly in medial borders (specimen No. 12). 

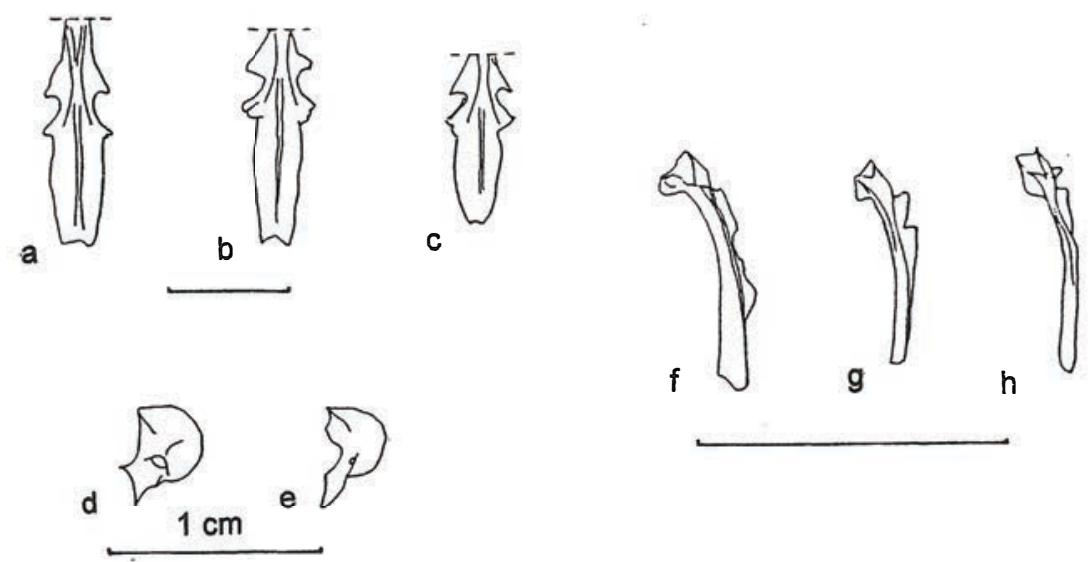

Fig. 8. Variability of bones: parasphenoid (a, b, c), pterosphenoid (d, e), and palatine (f, g, h); a, d, g-specimen no. 12 ; b, e, h—specimen no. $6 ; \mathrm{c}, \mathrm{f}-$ specimen no. 7

Infraorbital. There are no distinctive differences of the shape and size, but the number of these bones varies among specimens and within single specimen as well. Specimens Nos. 1 and 3 have 5 infraorbitals on each side of the body, but specimen No. 8 has 5 ones on the left, and 6 ones on the right.

Quadrate. There is a moderate variation on the posterior long outgrowth. It depends on differently formed edges and differently developed posterior tip of the outgrowth.

Palatine (Figs. 8f, g, h). Marked variability of the shape and size of the bone. Differences in the width of the posterior fragment, the length of whole element, forming of the anterior part and the medial edge take place.

Metapterygoid. Notable variability in the shape, particularly in its posterior, irregular part. There is a variability in proportions of edges within the anterior triangle component-in specimen No. 7 this fragment has longer anterior edge than in specimens Nos. 12 and 6. Notable differences of the shape in posterior parts of both metapterygoids are noticeable in specimen No. 12.

Hyomandibular. Not much variability, which concerns the shape of plates between outgrowths.

Symplectic. Medium variability, which marks itself in the form of bone edges.

Epihyal. An insignificant shape variability of the posterior process.

Ceratohyal. Small variability of the length of the posterior edge connected with similar lengths of whole bones-different proportions of lengths of borders.

Urohyal (Figs. 9a, b, c). Extensive variability of the bone shape and size. Differences particularly in the form of anterior and posterior borders. 
Preopercle. Moderate variability in the bone border shape and number, and the location of lateral line pores (there are 6 big pores in specimen No. 12, however, in specimen No. 6 there are as many as 8 pores). Variability of the medial part of the anterior border and the upper fragment of the bone visible between left and right preopercles.

Opercle (Figs. 9d, e, f). Significant variability of the shape visible in the posterior branch and upper outgrowth, and variability in the number of spines. Specimens Nos. 12, 7, and 1 have 4 spines on the posterior branch. In the specimen No. 7 they are deposited in equal spaces, but in specimens 12 and 1-irregularly. Specimens Nos. 6, 3, and 8 are equipped with 5 spines on the posterior edge. There is a small spine turned down on the upper outgrowth of specimen No. 7, however, in specimens Nos. 12 and 6 there are only a small convexity visible at the same place. Opercles left and right can be asymmetric (e.g. specimen No. 12).
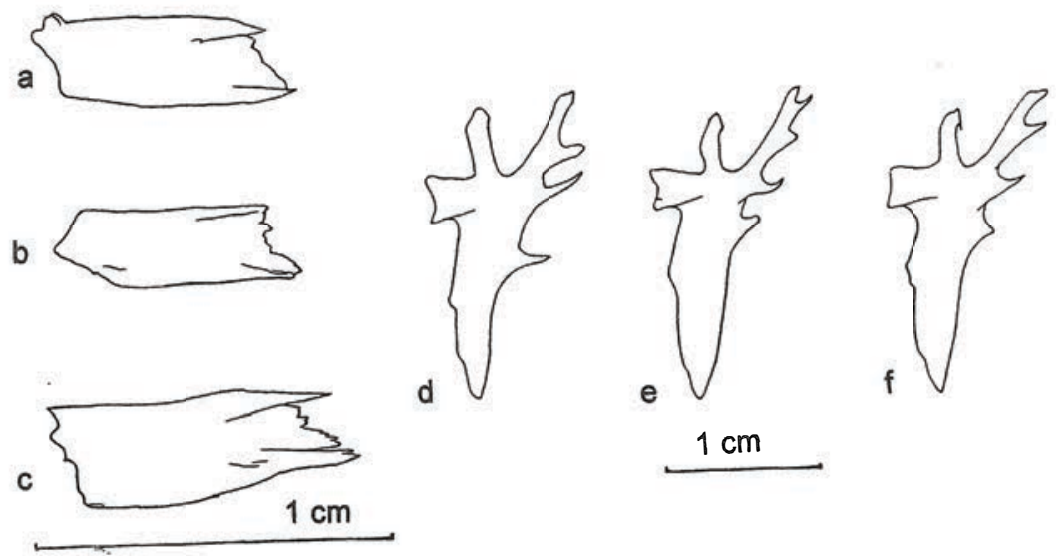

Fig. 9. Variability of bones: urohyal (a, b, c) and opercle (d, e, f); a, d-specimen no. 12; b, e-specimen no. 6 ; $c$, f-specimen no. 7

Subopercle. Medium variability only in the posterior spine.

Interopercle. Moderate variability only within the posterior spine. Differences in the shape and length.

Posttemporal. Some variability in shape. Differences occur in the direction of the bend of the posttemporal of specimens Nos. 6 and 12 .

Supracleithral. Medium variability concerning differences of the shape of the bone, particularly of the upper part, anterior and posterior borders. The sizes are also various: the supracleithral of the $7^{\text {th }}$ specimen is much longer than supracleithrals of specimens Nos. 12 and 6. 
The variability of bones of $C h$. wilsoni seems to be connected with a reduction of ossification. The variability is visible mostly in the structure of those elements which lost an important mechanical (supporting) function, because of being in the decline. Examples of such bones are: prevomer, pterosphenoid, palatine, urohyal, and opercular apparatus. Superficial elements which do not contact other bones and elements with free borders are also variable, e.g. ethmoid, the process of lateral ethmoid, frontal, nasal, pterotic, supraoccipital, opercle, posttemporal, supracleithral. The variability was confirmed on the surface of bones, which partially cover other ones or are covered by other bones, e.g. frontal (the medial border), parietal, parasphenoid (the posterior part), metapterygoid (the posterior component). Bones which perform important functions are typically not variable, e.g. brain case bones, bones of jaws, hyomandibular (a very small variability).

\section{RECAPITULATION}

Climate changes which took place in the Tertiary Period had significant effect on the biological history of the South Ocean. A distinct cooling of the climate took place at the boundary between the Eocene and Oligocene and it prompted certain evolutionary changes in the local organisms. One of the major directions was the evolutionary line resulting in evolvement of a specific group of fishes, which were later assigned to a separate suborder Notothenioidei. The Antarctic Circumpolar Current was formed at that time and in conjunction with the so called Antarctic Convergence, limited exchange of polar- and temperate waters. The processing cooling lasted through the Oligocene and Miocene and it contributed to the conquest of the Antarctic waters by notothenioids and to the displacement of the stenothermal fish fauna northwards. A substantial reduction of ossification that occurred in Ch. wilsoni and other channichthyid fishes could have been influenced indirectly by the maximum extent of the Antarctic glaciation at the boundary between the Miocene and Pliocene. Continental glaciers reached the edge of the shelf causing a partial damage to the shelf fauna and its displacement to deeper places (Baluškin 1992). Recent studies of the shelf prove that it does not exist as a proper shelf (because of is occupated by a glacier), but it has equivalent much deeper, on depths between 300 and 500-600 m. About $80 \%$ of fishes known from the Antarctic occur within this range of depths (Jakubowski 1971). Consequently the benthic fish fauna was pushed deeper down or partially passed to the pelagic zone. Such change of a mode of life forced the body mass to reduce because these fishes did not have a swimbladder. Probably that was the reason for the reduction of the skeleton mass through replacement of the bone by cartilage. This process can be interpreted as arrest of development of the skeleton in early phase and incomplete ossification of the primary cartilage skeleton. 
The reduction of ossification of $\mathrm{Ch}$. wilsoni has been manifested in a number of ways:

- replacement of whole bones with cartilage or only superficial ossification, e.g. the ethmoid cartilage, hypohyal, subopercle,

- separation of bones by wide cartilage areas, e.g. in the brain case, the mandibular arch, the hyoid arch,

- reduction of bone size without replacing bone tissue with cartilage, e.g. in the palatine arch, in extreme case - complete disappearance of a bone-opisthootic.

The variability of elements of the $C h$. wilsoni skeleton is closely related to a reduction of ossification. This variability is high in the case of reduced bones. It concerns paired elements as well. The variability of some bones, the shape and size not settled finally, can prove that the process of reduction is still in progress and the elements of the skeleton undergo continuous metamorphoses.

\section{REFERENCES}

Andriašev A.P., 1965: A general review of the Antarctic fish fauna. Monogr. Biol., 15: 491-550. (after Iwami 1985).

Baluškin A.V., 1992: Klassifikaciâ, rodstvennye sviazi i proishoždenie semejstv podotrâda nototenioidnyh ryb (Notothenioidei, Pisces) [Classification, interrelationships, and origin of the families in the suborder Notothenioidei, Pisces]. Voprosy Ichtiol., 32, 3: 3-19. (In Russian).

DeWitt H.H., 1971: Coastal and Deep-water Benthic Fishes of the Antarctic. Am. Geogr. Soc., New York (Anarct. Map Folio, ser. Folio 15). (after Iwami 1985).

Gerasimčuk B.B., B.G. Trocenko, 1988: Nekotorye voprosy ekologji Chaenodraco wilsoni Regan, 1914 (Channichthyidae, Percifonnes) [Some questions of ecology of Chaenodraco wilsoni Regan, 1914 (Channichthyidae, Perciformes)]. Antarktika, No. 27, Nauka, Moskva: 191-201. (In Russian).

Gill T.N., 1862: Synopsis of the chaenichthyoids, harpagiferoids, notothenioids. Proc. Acad. Nat. Sci. Philadelphia: 507-522. (after Iwami 1985).

Holcik J., 1989: The Freshwater Fishes of Europe, Vol.1, Part II: General Introduction to Fishes Acipenseriformes. Aula-Verlag, Wiesbaden.

Hollister G., 1934: Clearing and dyeing fish for bone study. Zoologica (Sc. Contr. New York Zool. Soc.), 12, 10: 15-18.

Iwami T., 1985: Osteology and relationships of the family Chaenichthyidae. Mem. Natl. Inst. Polar. Res., Ser. E, No. 36, Tokyo: 1-69.

Jakubowski M., 1971: Białokrwistość i inne osobliwości ichtiofauny Antarktyki [White-bloodedness and other peculiarities of the Antarctic ichthyofauna]. Przegl. Zool., 15, 3: 262-272. (In Polish).

Janec-Susłowska W., 1957: Osteologia szczupaka [Osteology of the pike]. PWN, Warszawa. (In Polish). 
Norman J.R., 1938: Coast fishes. Part III. The Antarctic zone. Discovery Rep., 18. (after Iwami 1985).

Olsen S., 1955: Contribution of the systematics and biology of chaenichthyid fishes from South Georgia. Nytt Magazin for Zoologi, 3, Akademisk Forlag, Oslo: 79-93.

Permitin Û.E., 1977: Vidovoj sostav i zoografičeskij analiz fauny donnyh ryb moria Skotija [A species composition and zoogeographical analysis of the benthic fish fauna of the Scott Sea]. Voprosy Ichtiol., 17, 5: 843-861. (In Russian).

Regan C.T., 1913: The Antarctic fishes of the Scotish National Expedition. Trans. Roy. Soc. Edinburgh, 49: 229-292. (after Iwami 1985).

Regan C.T., 1914: Fishes. Br. Antarct. ("Terra Nova") Exped. 1910. Nat. Hist. Rep., Zool., $1,1$. (after Iwami 1985).

Urbanowicz K., 1956: Osteologia karpia [Osteology of the carp]. PWN Warszawa. (In Polish).

Voskobojnikova O.S., 1982: O redukcii krylovidnych kostej visceral'nogo skeleta $\mathrm{v}$ processe specializacii ryb podotriada Notothenioidei (Perciformes) [On reduction of the visceral skeleton pterygoids in the process of specialisation of fishes from the suborder Notothenioidei (Perciformes)]. Voprosy Ichtiol., 22, 5: 832-839. (In Russian).

Voskobojnikova O.S., 1986: Evolucionnye preobrazovanija visceral'nogo skeleta i voprosy filogenii nototenievych ryb (Nototheniidae) [Evolution of the visceral skeleton and phylogeny of the Nototheniidae]. Trudy Zool. Inst. AN SSSR, 153: 46-66. (In Russian).

\section{Michał ŻABROWSKI}

\section{OSTEOLOGIA I ZMIENNOŚĆ SKOSTNIEŃ CZASZKI ANTARKTYCZNEGO GATUNKU CHAENODRACO WILSONI REGAN, 1914 (CHANNICHTHYIDAE, NOTOTHENIOIDEI, PISCES)}

\section{STRESZCZENIE}

Przeprowadzono szczegółową analizę czaszki antarktycznego gatunku Chaenodraco wilsoni Regan, 1914 (Channichthyidae, Notothenioidei, Pisces) pod kątem struktury poszczególnych skostnień, jak i zmienności osteologicznej. Zaobserwowano znaczną redukcję skostnień, mającą charakter zastapienia całych skostnień chrząstką lub tylko powierzchniowego kostnienia (np. w rejonie węchowym), rozdzielenia skostnień szerokimi pasmami chrząstki (np. w obrębie puszki mózgowej), redukcji rozmiarów kości. Skrajnym przypadkiem jest zupełny zanik opisthooticum stwierdzony po raz pierwszy u ryb tej rodziny. Redukcja skostnień u Chaenodraco wilsoni pociaga za sobą wysoką zmienność osteologiczną, obserwowaną w przypadku kości zredukowanych. Zaobserwowano także przypadki asymetrii parzystych elementów szkieletu.

Authors' address:

Michał Żabrowski MSc

Department of Paleozoology,

Zoological Institute

University of Wrocław

Sienkiewicza 21, 50-335 Wrocław, Poland

e-mail: zaba@biol.uni.wroc.pl 